\title{
PENGARUH KUALITAS PELAPORAN KEUANGAN TERHADAP INFORMASI ASIMETRI PADA PERUSAHAAN MAKANAN DAN MINUMAN DI BEI TAHUN 2010-2015
}

\author{
Fajar Pratiwiningsih \\ prathiwiecute@gmail.com \\ Jurusan Akuntansi, Fakultas Ekonomi, Universitas Islam Batik Surakarta
}

\begin{abstract}
ABSTRAK
Tujuan dari penelitian ini adalah: (1) Mengkaji isu-isu yang berkaitan dengan pengukuran kualitas pelaporan keuangan perusahaan. (2) Mengkaji isu-isu yang berkaitan dengan kualitas pelaporan keuangan perusahaan dengan fokus pada kajian faktor-faktor penentu dan informasi asimetrinya secara langsung. Populasi dalam penelitian ini adalah seluruh perusahaan manufaktur yang telah terdaftar (listed) di Bursa Efek Indonesia (BEI). Kriteria yang dijadikan dasar untuk pemilihan sampel adalah sebagai berikut: (1) Perusahaan menerbitkan laporan keuangan dengan periode pelaporan keuangan tahunan yang berakhir pada tanggal 31 Desember 2010-2015. (2) Perusahaan yang memiliki data harga penutupan saham, harga permintaan, harga penawaran, bid volume dan volume perdagangan secara lengkap. Dalam penelitian ini instrument penelitiannya adalah dokumentasi, data yang dikumpulkan diperoleh dari data-data mengenai laporan keuangan auditan perusahaan manufaktur yang terdapat di Bursa Efek Indonesia (BEI) yang dipublikasikan kepada publik melalui massa dalam hal ini dalam Indonesia Stock exchange web www.idx.ci.id. Penelitian ini bertujuan untuk mengetahui pengaruh kualitas pelaporan keuangan (relevansi nilai, ketepatwaktuan, dan konservatisme) terhadap informasi asimetri pada perusahaan manufaktur yang terdaftar di Bursa Efek Indonesia tahun 2010-2015. Berdasarkan hasil pengujian hipotesis menunjukkan bahwa: atribut-atribut kualitas pelaporan keuangan (relevansi nilai, ketepatwaktuan, dan konservatisme) merupakan representasi kualitas pelaporan keuangan, dan berbeda satu dengan lainnya. Hal tersebut dibuktikan dari hasil nilai regresi auxiliary $R^{2}$ yang tertinggi ketepatwaktuan sebesar 0,343; relevansi nilai sebesar 0,278 dan koservatif sebesar 0,187. Dari hasil yang menunjukkan tidak ada kesamaan. Ketiga atribut kualitas pelaporan keuangan dapat membentuk 1 faktor dimana variabel baru yang terbentuk didukung oleh keseluruhan atribut kualitas pelaporan keuangan. Hasil tersebut ditunjukkan perhitungan menggunakan uji $\mathrm{F}=7,525>$ Ftabel $=3,20$ dengan signifikansi $-0,027<0,05$. Hipotesis tersebut terbukti dengan hasil sig. sebesar -0.027 yang artinya, kualitas pelaporan keuangan berpengaruh negatif secara signifikan terhadap informasi asimetri. Maksudnya, semakin tinggi kualitas pelaporan keuangan suatu perusahaan, maka akan semakin rendah informasi asimetri.
\end{abstract}

\section{Kata kunci : Kualitas Pelaporan Keuangan, Informasi Asimetri}




\section{PENDAHULUAN}

Perkembangan bisnis di Indonesia dari tahun ke tahun semakin berkembang pesat. Pada masa sekarang ini semakin banyak para investor yang menginvestasikan modalnya di Indonesia, baik investor dari dalam negeri maupun luar negeri. Pertumbuhan pasar modal di Indonesia sekarang ini telah meningkat sangat pesat dan tentunya dimasa mendatang bisnis investasi ini akan menjadi sedemikian berpengaruh dengan persaingan yang semakin ketat. Salah satu sumber informasi yang penting dalam bisnis investasi pasar modal adalah laporan keuangan yang disediakan setiap perusahaan yang terdaftar di Bursa Efek Indonesia yang telah go public.

Pada mulanya laporan keuangan bagi suatu perusahaan hanyalah sebagai "alat penguji" dari pekerjaan bagian pembukuan, tetapi untuk selanjutnya laporan keuangan tidak hanya sebagai alat penguji saja tetapi sebagai dasar untuk dapat menentukan atau menilai posisi keuangan perusahaan, dimana dengan hasil analisa tersebut pihak-pihak yang berkepentingan mengambil suatu keputusan. Laporan keuangan pada dasarnya adalah hasil dari proses akuntansi yang dapat digunakan sebagai alat berkomunikasi antara data keuangan atau aktivitas suatu perusahaan dengan pihak-pihak yang berkepentingan dengan data atau aktivitas perusahaan tersebut (Munawir, 2004).

Pada prinsipnya pengertian kualitas pelaporan keuangan dapat dipandang melalui dua sudut pandang. Pandangan pertama menyatakan bahwa kualitas pelaporan keuangan berhubungan dengan kinerja keseluruhan perusahaan, yang dicerminkan dalam laba yang diperoleh perusahaan. Dalam pandangan ini dinyatakan laba yang memiliki kualitas tinggi dilihat dari laba yang berkesinambungan (sustainable), dan dalam periode waktu yang panjang. Dalam pandangan ke 2 dinyatakan bahwa kualitas pelaporan keuangan berkaitan dengan kinerja di pasar modal yang di wujudkan dalam bentuk return, sehingga jika hubungan laba perusahaan dan return kuat, maka menunjukan informasi pelaporan keuangan yang tinggi (Ayres, 1994 dalam Fanani, 2009).

Kualitas pelaporan keuangan yang baik akan mengurangi resiko terjadinya ketidaksempurnaan informasi dikalangan pengguna laporan keuangan atau asimetri informasi (Copeland dan Galai, 1983). Informasi yang dibutuhkan pemilik sering kali disampaikan berbeda atau tidak sesuai dengan kondisi sesungguhnya. Kondisi seperti ini disebut informasi yang tidak simetris atau asimetri informasi, atau dapat disebut juga ketidaksempurnaan informasi. Sehingga dapat dikatakan bahwa kualitas pelaporan keuangan memiliki pengaruh terhadap terjadinya asimetri informasi. Terjadinya asimetri informasi karena manajer menguasai informasi lebih superior dibanding pihak lain (pemilik atau pemegang saham).

Kualitas pelaporan keuangan dikaji melalui tiga atribut kualitas pelaporan keuangan berdasarkan pasar yaitu relevansi nilai, ketepatwaktuan, dan konservatisme. Ketiga atribut ini akan memberikan daya penjelas yang lebih beragam mengenai kualitas pelaporan keuangan dan dapat menjelaskan faktor yang menentukan 
asimetri informasi yang terjadi di perusahaan secara langsung (Fanani, 2009).

Asimetri informasi kemungkinan terjadi lebih besar ketika pihak internal perusahaan memiliki informasi kinerja perusahaan yang buruk, seperti dan memiliki sedikit informasi kinerja perusahaan yang baik. Hal ini akan berdampak pihak internal perusahaan tidak bersedia memberikan informasi yang buruk tentang perusahaan, dan lebih memilih untuk memberikan informasi yang baik (Cheng dkk, 2010). Informasi yang baik dilihat dengan ada pengumuman kenaikan pembiayaan dan dividen, sedangkan informasi yang buruk dilihat dari menurunnya pembiayaan dan dividen (atau dividen nol).

Penelitian tentang pengaruh kualitas pelaporan keuangan telah banyak dilakukan, di Indonesia sendiri dilakukan oleh Fanani (2009) meneliti pengaruh kualitas pelaporan keuangan berbagai faktor penentu dan konsekuensi ekonomis. Hasil penelitiannya yaitu kualitas pelaporan keuangan berpengaruh negatif dan signifikan terhadap informasi asimetri, dengan menggunakan kualitas pelaporan keuangan faktorial yang terdiri atas relevansi nilai dan konservatisme sebagai atribut kualitas pelaporan keuangan.

Rini Indriani dan Wahiddatul Khoiriyah (2010) meneliti pengaruh kualitas pelaporan keuangan terhadap informasi asimetri. Hasil penelitian berbeda dengan hasil penelitian sebelumnya, yaitu ketiga atribut (relevansi nilai, ketepatwaktuan, dan konservatisme) dapat merepresentasikan kualitas pelaporan keuangan, dan pengaruh kualitas pelaporan keuangan terhadap konsekuensi ekonomis menunjukkan hasil yang tidak signifikan dan berpengaruh positif.

\section{METODE PENELITIAN}

1. Jenis Penelitian

Jenis penelitian ini adalah penelitian kuantitatif yaitu penelitian ini menekankan analisis pada data numerial (angka) yang diolah dengan data statistik.

2. Sumber Data dan Responden

Dalam penelitian ini data didapatkan dari hasil dokumentasi atau data sekunder. Data sekunder adalah merupakan sumber data penelitian yang diperoleh peneliti secara tidak langsung melalui media perantara (diperoleh dan dicatat oleh pihak lain). Data sekunder untuk penelitian ini diperoleh dari literatur-literatur yang mempunyai hubungan erat dengan objek penelitian, antara lain annual report (laporan keuangan) yang dipublikasikan di situs resmi Bursa Efek Indonesia (BEI).

\section{Populasi dan Sampling}

Populasi dalam penelitian ini adalah seluruh perusahaan manufaktur yang telah terdaftar (listed) di Bursa Efek Indonesia (BEI). Sampel dipilih dengan metode pemilihan sampel yang menggunakan pemilihan sampel bertujuan (purposive sampling) dengan berdasarkan pertimbangan (judgment sampling) (Indriantoro dan Supomo, 2002). Kriteria yang dijadikan dasar untuk pemilihan sampel adalah sebagai berikut: 1) Perusahaan menerbitkan laporan keuangan dengan periode pelaporan keuangan tahunan yang berakhir pada tanggal 31 Desember 20102015. 2) Perusahaan yang memiliki data 
harga penutupan saham, harga permintaan, harga penawaran, bid volume dan volume perdagangan secara lengkap.

4. Instrumen Penelitian

Bagian ini dijelaskan alat yang digunakan untuk mengumpulkan data. Dalam penelitian ini instrument penelitiannya adalah dokumentasi, data yang dikumpulkan diperoleh dari datadata mengenai laporan keuangan auditan perusahaan manufaktur yang terdapat di Bursa Efek Indonesia (BEI) yang dipublikasikan kepada publik melalui massa dalam hal ini dalam Indonesia Stock exchange web www.idx.ci.id.

5. Metode Analisis Data

\section{a. Statistik deskriptif}

Statistik deskriptif digunakan untuk mendeskripsikan dan memberi gambaran tentang distribusi frekuensi variabel-variabel dalam penelitian ini, nilai maksimum, minimum, rata-rata (mean) dan standar deviasi. Variabel kualitas pelaporan keuangan sebagai variabel independen dalam penelitian ini dapat diatribusikan dalam tiga atribut yaitu relevansi nilai, ketepatwaktuan, dan konservatisme, sedangkan pengukuran variabel dependen menggunakan informasi asimetri.

b. Uji asumsi klasik

Uji asumsi klasik yang dilakukan dalam penelitian ini terdiri dari :

1) Uji Normalitas

Uji normalitas bertujuan untuk menguji apakah dalam model regresi variabel pengganggu atau residual memiliki distribusi normal atau tidak. Seperti diketahui bahwa uji $\mathrm{t}$ dan $\mathrm{F}$ mengasumsikan bahwa nilai residual mengikuti distribusi normal. Apabila asumsi ini dilanggar maka uji statistik menjadi tidak berlaku (Ghozali, 2005). Sedangkan alat yang dikatakan normal apabila terjadi penyebaran antara variabel bebas dan terikat dilakukan pengujian normalitas data dengan menggunakan teknik statistik One Sample Kolmogorow Smirnov (Ghozali, 2005).

2) Uji Multikolinieritas

Uji multikolinearitas berarti ada hubungan linear yang sempurna atau pasti antara beberapa atau semua variabel independen dari model yang ada. Adanya multikolinearitas menyebabkan standard error cenderung semakin besar dengan meningkatnya tingkat korelasi antar variabel dan standard error menjadi sangat sensitif terhadap perubahan data. Variabel yang menyatakan multikolinearitas dapat dilihat dari nilai tolerance yang lebih kecil dari 0,1 atau nilai Variance Inflantion Factor (VIF) yang lebih besar dari 10.

3) Uji heteroskedastisitas 
Uji heterokedastisitas bertujuan menguji apakah dalam model terjadi ketidaksamaan variance dari residual satu pengamatan ke pengamatan yang lain (Ghozali, 2005). Heterokedastisitas yaitu variabel pengganggu (e) memilki varian yang berbeda dari satu observasi ke observasi lainya atau varian antar variabel independen tidak sama. Hal ini melanggar asumsi heterokedastisitas yaitu setiap variabel penjelas memiliki varians yang sama (konstan)

4) Uji autokorelasi

Autokorelasi adalah korelasi antara anggota-anggota serangkaian observasi yang diuraikan menurut waktu dan ruang (Gujarati, 2003 : 201). Konsekuensi adanya autokorelasi diantaranya adanya selang keyakinan menjadi lebar serta variasi dan standar error terlalu rendah.

c. Uji Hipotesis

1) Model Hipotesis 1

$$
\text { Uji hipotesis } 1
$$
menggunakan regresi berganda untuk mengetahui pengaruh antara dua variabel yaitu variabel independen dengan variabel dependen. Variabel independen yaitu variabel relevansi nilai, ketepatwaktuan, dan konservatisme, serta variabel dependennya yaitu informasi asimetri..

2) Model Hipotesis 2
Hipotesis 2 menggunakan model regresi sederhana dalam penelitian ini untuk menguji pengaruh kualitas pelaporan keuangan terhadap informasi asimetri.

3) Uji Hipotesis 1 (Uji F)

Uji $F$ pada dasarnya dimaksudkan untuk membuktikan secara statistik bahwa seluruh variabel independen berpengaruh secara bersama-sama terhadap variabel dependen, dengan hipotesis untuk menunjukkan apakah semua variabel bebas yang dimaksudkan dalam model mempunyai pengaruh secara bersamasama terhadap variabel tak bebas.

4) Uji Hipotesis 2 (Uji t)

Uji statistik $\mathrm{t}$ dilakukan untuk menunjukkan seberapa jauh pengaruh satu variabel penjelas atau independen secara individual dalam menerangkan variasi variabel dependen (Ghozali, 2005).

5) Uji Koefisien Determinan (R2) $\mathrm{R}^{2}$ bertujuan untuk mengetahui seberapa jauh variasi variabel independen dapat menerangkan dengan baik variasi variabel dependen. Untuk mengukur kebaikan suatu model (goodness of fit) dengan digunakan koefisien determinasi (R2). Koefisien determinasi (R2) merupakan angka yang memberikan proporsi atau persentase variasi total dalam 
variabel tak bebas (Y) yang dijelaskan oleh variabel bebas (X) (Gujarati, 2003).

\section{HASIL DAN PEMBAHASAN}

\section{Analisis Deskriptif}

\begin{abstract}
Statistik deskriptif digunakan untuk mendeskripsikan dan memberikan gambaran tentang distribusi frekuensi variabel-variabel dalam penelitian ini, nilai maksimum, minimum, rata-rata (mean) dan standar deviasi.
\end{abstract}

Tabel 1

Rangkuman Statistik Deskriptif

\begin{tabular}{lrrrr}
\hline \multicolumn{1}{c}{ Hasil } & Minimum & Maximum & Mean & \multicolumn{1}{c}{$\begin{array}{c}\text { Std. } \\
\text { Deviation }\end{array}$} \\
\hline Relevansi Nilai & 4.47 & 187.63 & 26.7612 & 44.79645 \\
Ketepatwaktuan & .20 & .70 & .5467 & .15097 \\
Konservatif & 5.38 & 778.66 & $3.2115 \mathrm{E} 2$ & 235.52950 \\
Pelaporan Keuangan & 4.28 & 41.85 & 15.4739 & 10.23494 \\
Informasi Asimetri & 4.35 & 266.26 & $1.1615 \mathrm{E} 2$ & 84.98949 \\
\hline
\end{tabular}

Sumber: Hasil Analisis Ststistik Deskriptif

Relevansi nilai diukur dengan laba untuk menjelaskan variasi dalam imbalan yang diterima oleh perusahaan merupakan hasil pembagian antara laba bersih dengan modal sendiri. Tabel 1 dapat dilihat bahwa rata-rata relevansi nilai perusahaan pada perusahaan makanan dan minuman di Bursa Efek Indonesia Tahun 2010-2015 sebesar $26,7612 \%$ dan standar deviasi sebesar
$44,79645 \%$ dimana nilai standar deviasinya lebih besar dari nilai rataratanya.

\section{Uji Asumsi Klasik}

a. Uji Normalitas

Hasil uji normalitas sebaran diperoleh menggunakan teknik statistik One Sample Kolmogorow Smirnov.

Tabel 2

\section{Rangkuman Hasil Normalitas}

\begin{tabular}{lcccc}
\hline \multicolumn{1}{c}{ Variabel } & $\begin{array}{c}\text { Kolmogorov- } \\
\text { Smirnov Z }\end{array}$ & $\begin{array}{c}\text { Asymp. } \\
\text { Sig. (2- } \\
\text { tailed) }\end{array}$ & $\begin{array}{c}\text { Standar } \\
\text { Sig. }\end{array}$ & Keterangan \\
\hline Relevansi Nilai & 3,127 & 0,926 & 0,05 & Normal \\
Ketepatwaktuan & 2,124 & 0,307 & 0,05 & Normal \\
Konservatif & 1,345 & 0,387 & 0,05 & Normal \\
Pelaporan Keuangan & 1,526 & 0,679 & 0,05 & Normal \\
Informasi Asimetri & 2,064 & 0,387 & 0,05 & Normal \\
\hline
\end{tabular}




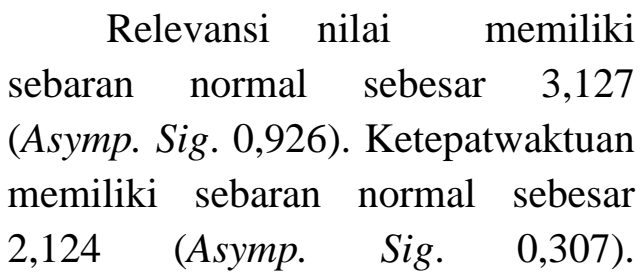
Konservatif memiliki sebaran normal dengan Kolmogorow Smirnov $Z$ sebesar 1,345 (Asymp. Sig. 0,387). Pelaporan keuangan memiliki sebaran normal dengan Kolmogorow Smirnov Z sebesar 1,526 (Asymp. Sig. 0,679). Informasi asimetri memiliki sebaran normal dengan Kolmogorow Smirnov $Z$ sebesar 2,064 (Asymp. Sig. 0,387). Dari hasil perhitungan Kolmogorow Smirnov dapat diketahui bahwa Asymp. Sig > $\mathrm{p}=0,05$ memiliki sebaran normal.

b. Uji Multikolinearitas

Hasil tersebut dapat diketahui melalui rangkuman hasil multikolinearitas pada tabel berikut ini.

Tabel 3

\section{Hasil Rangkuman Multikolinearitas}

\begin{tabular}{lrrll}
\hline Variabel & Tolerance & VIF & Standar & Keterangan \\
\hline Relevansi Nilai & 0,869 & 1.150 & $<10$ & $\begin{array}{l}\text { Tidak ada } \\
\text { multikolinearitas }\end{array}$ \\
Ketepatwaktuan & 0,877 & 1.140 & $<10$ & $\begin{array}{l}\text { Tidak ada } \\
\text { multikolinearitas }\end{array}$ \\
Konservatif & 0,769 & 1.300 & $<10$ & $\begin{array}{l}\text { Tidak ada } \\
\text { multikolinearitas }\end{array}$ \\
\hline
\end{tabular}

Sumber: Hasil Uji Asumsi

Hasil perhitungan nilai tolerance juga menunjukkan ada variabel bebas yang memiliki nilai tolerance kurang dari $10 \%$ yang berarti tidak ada korelasi antar variabel bebas yang nilainya lebih dari $95 \%$. Variabel yang tidak ada multikolinearitas hasil penghitungan Varience Inflation Factor (VIF) kurang dari 10 yaitu relevansi nilai dengan VIF sebesar $1,150<10$, ketapatwaktuan dengan VIF sebesar 1,140, dan konservatif dengan VIF sebesar $1,300<10$.

c. Uji Heteroskedastisitas

Pengujian heteroskedastisitas dilakukan dengan menggunakan nilai residual sebagai variabel dependen yang diperoleh dari analisis regresi biasa 
Tabel 4

Hasil Rangkuman Multikolinearitas

\begin{tabular}{ccccccc}
\hline Variabel & $\begin{array}{c}\text { Std. } \\
\text { Error }\end{array}$ & Standar & Sig. & $\begin{array}{c}\text { Standar } \\
\text { Sig. }\end{array}$ & Keterangan \\
\hline Relevansi Nilai & 24,697 & 4,3026 & 0,041 & 0,05 & Terjadi heteroskedastisitas & Terjadi \\
Ketepatwaktuan & 26,532 & 4,3026 & 0,006 & 0,05 & $\begin{array}{c}\text { heteroskedastisitas } \\
\text { Terjadi }\end{array}$ \\
Konservatif & 30,045 & 4,3026 & 0,034 & 0,05 & heteroskedastisitas \\
\hline
\end{tabular}

Sumber: Hasil Uji Asumsi

\begin{tabular}{|c|c|}
\hline 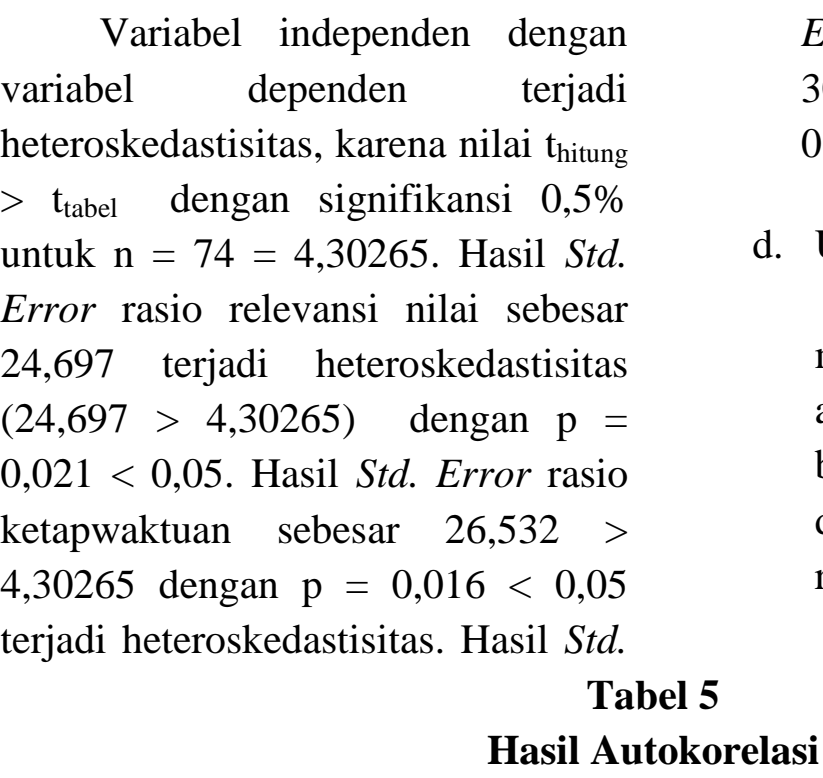 & $\begin{array}{l}\text { Uji Autokorelasi } \\
\text { Uji autokorelasi } \\
\text { menentukan tidak } \\
\text { autokorelasi atau kondi } \\
\text { berurutan diantara gangg } \\
\text { distribusi yang masuk dala } \\
\text { regresi populasi. }\end{array}$ \\
\hline Durbin-Watson & Keterangan \\
\hline $1,3832-2,3331$ & $\begin{array}{l}\text { Tidak ada autokorelasi } \\
\text { positif }\end{array}$ \\
\hline
\end{tabular}

Sumber: Hasil Uji Asumsi, Lampiran 4

Durbin Watson dengan 0.05 hitung sebesar 2,446 dan diketahui tabel Durbin-Watson (DW) untuk populasi sebesar 74 dan tiga variabel sebesar $=2,814$. Ini berarti ada autokorelasi sehingga kondisi yang berurutan diantara gangguan atau distribusi masuk dalam fungsi regresi populasi. Berdasarkan hasil tersebut dapat diketahui bahwa untuk sampel sebanyak $\mathrm{N}=75$ dan variabel yang menjelaskan sebanyak 3 macam variabel, maka nilai $\mathrm{D}-\mathrm{W}$ pada tingkat kepercayaan $5 \%$ adalah $\mathrm{dL}=$ 1,3832 dan nilai $\mathrm{du}=1,6662$ maka didapatkan nilai $3-$ dL yaitu $3-$ $1,3832=2,6168$ dan $3-$ du yaitu $3-$ $1,6662=2,3332$.

Dari hasil perhitungan dengan program SPSS memperoleh nilai 
Durbin Watson $(\mathrm{D}-\mathrm{W})=1,326$. Hal ini berarti nilai $\mathrm{D}-\mathrm{W}$ berada pada $\mathrm{D}-\mathrm{W}<\mathrm{du}$, yaitu $-1,3832<1,326<$ 2,3332, sehingga dapat dikatakan

\section{Tabel 6}

\section{Keputusan Ada Tidaknya Autokorelasi}

\begin{tabular}{lll}
\hline Hipotesis Nol & Keputusan & Jika \\
\hline Tdk ada autokorelasi positif & Tolak & $0<\mathrm{d}<\mathrm{dl}$ \\
Tdk ada autokorelasi positif & No decision & $\mathrm{dl} \leq \mathrm{d} \leq \mathrm{du}$ \\
Tdk ada korelasi negative & Tolak & $4-\mathrm{dl}<\mathrm{d}<4$ \\
Tdk ada korelasi negative & No decision & $4-\mathrm{du} \leq \mathrm{d} \leq 4-\mathrm{dl}$ \\
Tdk ada autokorelasi, Positif atau negatif & Tidak ditolak & $\mathrm{du}<\mathrm{d}<4-\mathrm{du}$ \\
\hline
\end{tabular}

\section{Uji Hipotesis}

a. Uji Model 1

Model 1 dalam penelitiaan ini menggunakan regresi berganda menolak $\mathrm{H}_{0}$, atau autokorelasi positif. Adapun stadar dari uji autokorelasi pada tabel berikut ini.

\section{Tabel 7}

\section{Hasil Uji Model 1}

\begin{tabular}{|c|c|c|}
\hline Variabel & Beta & Keterangan \\
\hline Constant & 13.809 & $\begin{array}{l}\text { Relevansi nilai, ketepatwaktuan, dan konservatif } \\
\text { adalah nol, laporan keuangan yang terjadi adalah } \\
\text { sebesar } 13,808 \%\end{array}$ \\
\hline Relevansi Nilai & 20.728 & $\begin{array}{l}\text { Setiap penambahan relevansi nilai } 1 \% \text {, akan } \\
\text { meningkatkan laporan keuangan } 20,728 \% \text {. }\end{array}$ \\
\hline Ketepatanv & 28.013 & $\begin{array}{l}\text { Setiap penambahan ketepatwaktuan } 1 \% \text {, akan } \\
\text { meningkatkan laporan keuangan sebesar } \\
20,013 \% \text {. }\end{array}$ \\
\hline Konservatif & 47.807 & $\begin{array}{l}\text { Setiap penambahan konservatif } 1 \% \text {, akan } \\
\text { meningkatkan laporan keuangan sebesar } \\
20,013 \% \text {. }\end{array}$ \\
\hline
\end{tabular}

b. Uji Model 2

Model 2 dalam penelitiaan ini menggunakan regresi sederhana melalui hasil olahan data dengan program SPSS, diperoleh hasil, sebagai berikut:

melalui hasil olahan data dengan program SPSS, diperoleh hasil, sebagai berikut: 


\section{Tabel 8}

Hasil Uji Model 2

\begin{tabular}{lcl}
\hline \multicolumn{1}{c}{ Variabel } & Beta & \multicolumn{1}{c}{ Keterangan } \\
\hline Constant & 87.699 & $\begin{array}{l}\text { Laporan keuangan adalah nol, maka informasi } \\
\text { asimetri yang terjadi adalah sebesar 13,808\% }\end{array}$ \\
$\begin{array}{l}\text { Laporam } \\
\text { Keuangan }\end{array}$ & 66.914 & $\begin{array}{l}\text { Setiap penambahan laporan keuangan 1\%, akan } \\
\text { meningkatkan informasi asimetri } 66,914 \% .\end{array}$ \\
\hline
\end{tabular}

c. Hasil Uji Hipotesis 1

Dalam persamaan pertama dan kedua digunakan taraf keyakinan 95 persen $(\alpha=5 \%)$, dengan $\mathrm{df}=74(\mathrm{n}-\mathrm{k}$
$=74-3=71$ ), maka diperoleh $\mathrm{F}$ tabel sebesar 1,89 dari hasil regresi persamaan.

\section{Tabel 9}

Nilai F-Statistic

\begin{tabular}{|l|l|l|l|l|c|}
\hline Variabel & \multicolumn{3}{|c|}{ Persamaan } & \multirow{2}{*}{ Keterangan } \\
\cline { 2 - 5 } & $\begin{array}{l}\text { F- } \\
\text { Statistic }\end{array}$ & Ftabel & Sig. & Standar & \\
\hline $\begin{array}{l}\text { Relevansi Nilai } 15,519 \\
\text { Ketepatwaktuan, } \\
\text { dan konservatif } \\
\text { dengan Kualitas }\end{array}$ & 1,89 & 0.018 & 0,05 & Diterima \\
Pelaporan & & & & \\
\hline
\end{tabular}

Tabel 10

Nilai t-Statistic

\begin{tabular}{|l|c|c|l|c|l|}
\hline Variabel & \multicolumn{4}{|c|}{ Persamaan } & \multirow{2}{*}{ Keterangan } \\
\cline { 2 - 5 } & t-Statistic & ttabel & Sig. & \multicolumn{1}{|c|}{ Standar } & \\
\hline Relevansi Nilai & 3,833 & 1,683 & 0,009 & 0,05 & Signifikan \\
\cline { 2 - 4 } \cline { 5 - 6 } Ketepatwaktuan & 6,582 & 1,683 & 0,016 & 0,05 & Signifikan \\
\cline { 2 - 5 } Konservatif & 4,563 & 1,683 & 0,043 & 0,05 & Signifikan \\
\hline
\end{tabular}

Berdasarkan tabel 8, dengan nilai t-tabel untuk persamaan di atas adalah sebesar 1,683 dapat disimpulkan bahwa pada persamaan variabel, yaitu relevansi nilai, ketepatwaktuan, dan konservatisme berpengaruh signifikan pada $\alpha=5 \%$ terhadap variabel dependen yaitu kualitas pelaporan keuangan.

Uji regresi auxiliary $R^{2}$ dan analisis faktor untuk membentuk variabel kualitas pelaporan keuangan. Hasil yang diperoleh 
setelah melakukan uji regresi

auxiliary $R^{2}$ disajikan dalam tabel 11 .

Tabel 11

\section{Regresi Auxiliary R2 dan Matriks Korelasi Antar Atribut Kualitas Pelaporan Keuangan}

\begin{tabular}{|c|c|}
\hline Atribut Kualitas Pelaporan Keuangan & \multicolumn{1}{c|}{ Regresi auxiliary $\mathbf{R}^{\mathbf{2}}$} \\
\hline Relevansi Nilai & 0.278 \\
\cline { 2 - 2 } Ketepatwaktuan & 0,343 \\
Konservatif & 0,187 \\
\cline { 2 - 2 }
\end{tabular}

Pada tabel 11 di atas menunjukkan bahwa Atribut relevansi nilai memiliki nilai regresi auxiliary $R^{2}$ yang tertinggi sebesar 0,278; kemudian ketepatwaktuan sebesar 0,343; dan koservatif sebesar 0,187 .

\section{Uji Hipotesis 2}

Hasil analisis faktor ketiga atribut kualitas pelaporan keuangan terhadap informasi asimetri dapat dilihat pada tabel 12.

Tabel 12

Nilai F-Statistic

\begin{tabular}{|l|l|l|l|l|l|}
\hline \multirow{2}{*}{ Variabel } & \multicolumn{4}{|c|}{ Persamaan } & Keterangan \\
\cline { 2 - 5 } & F-Statistic & Ftabel & Sig. & Standar & \\
\hline Atribut & 7.525 & 3,20 & - & 0,05 & Signifikan \\
Kualitas & & & 0.027 & & \\
Pelaporan & & & & & \\
Keuangan & & & & & \\
dan & & & & \\
Informasi & & & & \\
Asimetri & & & & & \\
\hline
\end{tabular}

Berdasarkan hasil analisis yang disajikan dalam tabel tersebut, ditunjukkan bahwa dari ketiga atribut kualitas pelaporan keuangan dapat membentuk 1 faktor dimana variabel baru yang terbentuk didukung oleh keseluruhan atribut kualitas pelaporan keuangan. Hasil tersebut ditunjukkan perhitungan menggunakan uji $\mathrm{F}=$
7,525 $>$ Ftabel $=3,20$ dengan signifikansi $-0,027<0,05$.

5. Pembahasan

a. Pembahasan Hipotesis Pertama

Berdasarkan hasil uji hipotesis, atribut relevansi nilai memiliki nilai regresi auxiliary $R^{2}$ yang tertinggi ketepatwaktuan sebesar 0,343; relevansi nilai sebesar 0,278; dan koservatif sebesar 0,187. 
Dari hasil yang menunjukkan tidak ada kesamaan.

1) Kualitas Pelaporan Keuangan (Ketepatwaktuan)

Ketepatwaktuan

mempunyai pengaruh yang

paling besar (0,343).

Ketepatwaktuan merupakan

kualitas yang berkaitan dengan ketersediaan informasi pada saat dibutuhkan. Informasi yang sebenarnya bernilai prediksi tinggi dapat menjadi tidak relevan kalau tidak tersedia pada saat dibutuhkan.

Pengukuran ketepatan waktu pelaporan keuangan diukur berdasarkan keterlambatan pelaporan keuangan perusahaan, sesuai dengan yang digunakan. Pengukuran ketepatan waktu pelaporan keuangan perusahaan didasarkan pada peraturan yang ditetapkan oleh BAPEPAM pada tanggal 30 September 2003 bersadarkan Nomor: Kep/36/PM/2003 yang menyatakan bahwa laporan keuangan tahunan. Peraturan BAPEPAM, X.K.6 tertanggal 7 Desember 2006 menyatakan penyampaian laporan keuangan tahunan dikatakan tepat waktu apabila diserahkan sebelum sebelum atau paling lambat pada akhir bulan ketiga setelah tanggal laporan keuangan tahunan perusahaan public.

Penelitian mengenai ketepatan waktu merupakan pengembangan lebih lanjut dari agency theory yang menunjukkan adanya perbedaan pandangan dan kepentingan antara principle dan agent. Lebih lanjut pandangan yang mendukung konsep ini adalah menurut Kim dan Verrechia (dalam Astriyana, dkk., 2015) yang mengemukakan bahwa laporan keuangan yang tepat waktu akan mengurangi informasi asimetri tersebut.

2) Kualitas Pelaporan Keuangan (Relevansi Nilai)

Berdasarkan hasil uji hipotesis menunjukkan bahwa relevansi nilai mempunyai pengaruh yang paling kecil $(0,278)$. Relevan artinya bahwa informasi tersebut dapat membantu para pengguna laporan keuangan dalam membuat keputusan ekonomi. Informasi yang relevan akan membantu pemakai membuat prediksi tentang hasil akhir dari kejadian masa lalu, masa kini, dan masa depan; yaitu, memiliki nilai prediktif. Informasi yang relevan juga membantu pemakai menjustifikasi atau mengoreksi ekspektasi atau harapan masa lalu; yaitu, memiliki nilai umpan balik.

Relevansi nilai didefinisikan oleh Beaver (Setiany dan Wulandari, 2015) sebagai kemampuan informasi akuntansi untuk menjelaskan nilai perusahaan. Terdapat dua tipe model penilaian yang dapat digunakan untuk menginvestigasi 
hubungan tersebut yaitu model harga (hubungan harga saham dengan nilai buku dan earnings) dan model return (hubungan return saham dengan earnings dan perubahan earnings). Relevansi nilai pada dasarnya adalah kemampuan laba dalam menjelaskan variasi pada return, dengan ekpektasi laba tersebut mempunyai kemampuan yang lebih besar untuk menjelaskan variasi return yang terjadi. Konsep relevansi nilai akuntansi sesungguhnya menjelaskan mengenai bagaimana investor bereaksi terhadap pengumuman informasi akuntansi. Reaksi yang terjadi membuktikan bahwa kandungan informasi akuntansi merupakan isu yang sangat penting menjadi pertimbangan penting dalam proses pengambilan keputusan investasi yang bermanfaat bagi investor.

Secara umum, hasil penelitian ini berbeda dengan penelitian sebelumnya yang dilakukan oleh Indriani dan Khoiriyah (2010) dengan kesimpulannya bahwa ketiga atribut (relevansi nilai, ketepatwaktuan dan koservatisme) dapat merepresentasikan kualitas pelaporan keuangan, dan pengaruh kualitas pelaporan keuangan terhadap konsekuensi ekonomis menunjukkan hasil yang tidak signifikan dan berpengaruh positif.
3) Kualitas Pelaporan Keuangan (Konservatif)

Berdasarkan hasil uji hipotesis konservatif menunjukkan pengaruh terbesar yang kedua setelah faktor ketepatwaktuan $(0,187)$. Swasta (2007) mendefinisikan konservatisme sebagai praktik mengurangi laba (mengecilkan aktiva bersih) dalam merespons berita buruk (bad news), tetapi tidak meningkatkan laba (meninggikan aktiva bersih) dalam merespons berita baik (good news).

Penman dan Zhang (2002) menyatakan bahwa karakteristik dari konservatisme adalah net assets yang dilaporkan di laporan keuangan lebih rendah dibandingkan nilai pasarnya dalam jangka panjang. Konservatisme merupakan reaksi yang berhati-hati atas ketidakpastian yang ada, sedemikian rupa agar ketidakpastian tersebut dan risiko yang berkaitan dalam situasi bisnis bisa dipertimbangkan dengan cukup memadai.

Penerapan prinsip ini mengakibatkan pilihan metode akuntansi Astriyana, dkk (2015) menjelaskan bahwa konservatisme dalam akuntansi ini mengimplikasikan adanya persyaratan verifikasi yang asimetris antara pengakuan laba dan rugi. Oleh karena itu, semakin tinggi tingkat perbedaan 
dalam verifikasi yang disyaratkan untuk pengakuan laba versus pengakuan rugi, maka semakin tinggi tingkat konservatisme akuntansinya. Salah satu pengukuran integritas laporan keuangan adalah dengan menggunakan indeks konservatisme akuntansi yaitu dengan menggunakan asumsiasumsi metode perusahaan yang digunakan antara lain metode penyusutan, metode depresiasi dan amortisasi, serta pengakuan biaya riset. Konservatisme sebagai reaksi hati-hati (prudent reaction) menghadapi ketidakpastian. Hal ini dilakukan untuk memastikan bahwa ketidakpastian dan resiko yang melekat pada situasi bisnis telah cukup dipertimbangkan.

\section{b. Pembahasan Hipotesis Kedua}

Berdasarkan hasil pengujian menunjukkan bahwa ketiga atribut kualitas keuangan secara bersamasama mempengaruhi informasi asimetri. Hipotesis tersebut terbukti dengan hasil sig. sebesar -0.027 yang artinya, kualitas pelaporan keuangan berpengaruh negatif secara signifikan terhadap informasi asimetri. Maksudnya, semakin tinggi kualitas pelaporan keuangan suatu perusahaan, maka akan semakin rendah informasi asimetri.

Cohen (2003) menjelaskan bahwa konsekuensi ekonomis kualitas informasi pelaporan keuangan yang ditimbulkan bagi penilaian investor dapat berupa informasi asimetri. Informasi asimetri menandakan adanya ketidakseimbangan informasi yang diperoleh investor dan manajer perusahaan. Penelitian Copeland dan Galai menemukan bahwa ketika kualitas informasi akuntansi mengalami peningkatan, maka informasi asimetri akan mengalami penurunan atau dengan kata lain kualitas informasi akuntansi yang disampaikan melalui pelaporan keuangan memiliki pengaruh yang negatif terhadap informasi asimetri. Fanani (2009) juga menemukan hal yang sama dengan penelitian yang dilakukan oleh Copeland dan Galai yaitu kualitas pelaporan keuangan berpengaruh negatif dan signifikan terhadap informasi asimetri.

Adanya pengaruh negatif pelaporan keuangan terhadap informasi asimetri, dijelaskan oleh Haniati dan Fitriany (2010), bahwa secara teori asimetri informasi berasal dari pengusaha dalam pasar tenaga kerja yang sering memiliki informasi lebih banyak tentang status sekarang dan mendatang perusahaannya, dan dapat menggunakan kelebihan ini sebagai basis negosiasi. Hal ini dapat dilihat sebagai suatu ketidaksempurnaan dalam bekerjanya mekanisme pasar dan bisa menyebabkan efesiensi ekonomik. Kondisi seperti ini membuat manajemen memanfaatkan ketidakselarasan informasi untuk keuntungan manajemen sendiri serta sekaligus merugikan pihak luar 
perusahaan seperti membiaskan informasi yang terkait dengan investor.

\section{KESIMPULAN DAN SARAN}

Penelitian ini bertujuan untuk mengetahui pengaruh kualitas pelaporan keuangan (relevansi nilai, ketepatwaktuan, dan konservatisme) terhadap informasi asimetri pada perusahaan manufaktur yang terdaftar di Bursa Efek Indonesia tahun 2010-2015. Berdasarkan hasil pengujian hipotesis menunjukkan bahwa: (1) atributatribut kualitas pelaporan keuangan (relevansi nilai, ketepatwaktuan, dan konservatisme) merupakan representasi kualitas pelaporan keuangan, dan berbeda satu dengan lainnya. Hal tersebut dibuktikan dari hasil nilai regresi auxiliary $R^{2}$ yang tertinggi ketepatwaktuan sebesar 0,343 ; relevansi nilai sebesar 0,278 dan koservatif sebesar 0,187. Dari hasil yang menunjukkan tidak ada kesamaan.

Ketiga atribut kualitas pelaporan keuangan dapat membentuk 1 faktor dimana variabel baru yang terbentuk didukung oleh keseluruhan atribut kualitas pelaporan keuangan. Hasil tersebut ditunjukkan perhitungan menggunakan uji $\mathrm{F}=7,525>$ Ftabel $=3,20$ dengan signifikansi $-0,027<0,05$. Hipotesis tersebut terbukti dengan hasil sig. sebesar 0.027 yang artinya, kualitas pelaporan keuangan berpengaruh negatif secara signifikan terhadap informasi asimetri. Maksudnya, semakin tinggi kualitas pelaporan keuangan suatu perusahaan, maka akan semakin rendah informasi asimetri

\section{Keterbatasan}

Penelitian ini memiliki beberapa keterbatasan yang dalam penelitian selanjutnya akan dikembangkan ke yang lebih baik lagi yaitu:

1. Dalam penelitian ini hanya menggunakan perusahaan manufaktur sebagai sampel sehingga hasil penelitian ini tidak dapat digeneralisasikan pada jenis perusahaan lain seperti telekomunikasi, perbankan, atau transportasi.

2. Penelitian ini hanya mengacu pada website Bursa Efek Indonesia sehingga didapat hanya beberapa sebab ada beberapa perusahaan yang tidak melaporkannya ke website Bursa Efek Indonesia.

\section{Saran}

Saran penelitian ini ditujukan kepada peneliti selanjutnya dengan judul yang sesuai dalam penelitian. Mengingat dalam penelitian ini ada dua kelamahan atau keterbatasan, maka peneliti menyarankan pada peneliti selanjutnya, sebagai berikut:

1. Bagi peneliti selanjutnya dalam melakukan perusahaan manufaktur sebagai sampel disarankan untuk melakukan pada jenis perusahaan lain seperti telekomunikasi, perbankan, atau transportasi.

2. Disarankan bagi peneliti lain untuk dapat memperluas literatur tentang data perusahaan yang benar-benar memberikan laporan yang lengkap ke BEI, sehingga peneliti dalam mengolah data tidak kesulitan dan penelitian menjadi lebih baik. 


\section{DAFTAR PUSTAKA}

Astriyani, Gita, Amrizal, Sari Mita Nurmala, Hasanah Nurlaili, 2015, Pengaruh Kualitas Audit, Penghindaran Pajak dan Konservatisme Akuntansi Terhadap Timeliness Reporting (Studi Empiris pada Perusahaan Perbankan yang terdaftar di Bursa Efek Indonesia Tahun 2011-2015). Seminar Nasional dan The 3rd Call for Syariah Paper.

Copeland, T. and D. Galai, 1983, Information Effects On The BidAsk Spread. The Journal o $f$ Finance. 36. 1457-1469.

Cheng, M; Dhaliwal, D; and Zhang Y., 2010, Does Investment Efficiency Improve After the Disclosure of Material Weakness in Internal Control over Financial Reporting?, Journal Of Accounting and Economics. 56: 1-18.

Cohen, D. A., 2003, Quality of Financial Reporting Choice : Determinants and Economic Consequences. London Business School Accounting Symposium.

Fanani, Zaenal, 2009, Kualitas Pelaporan Keuangan: Berbagai Faktor Penentu Dan Konsekuensi Ekonomis, Jurnal Akuntansi dan Keuangan Indonesia. 6: 20-45.

Ghozali, Imam, 2005, Aplikasi Analisis Multivariate Dengan Program
SPSS. Edisi Revisi. Semarang: Universitas Diponegoro.

Gujarati, Darmodar, 2003, Ekonometrika Dasar. Terjemahan Sumarno Zein. Jakarta: Erlangga.

Haniati, Sri dan Fitriany, 2010, Pengaruh Konservatisme Terhadap Asimetri Informasi dengan Menggunakan Beberapa Model Pengukuran Konservatisme. Simposium Nasional Akuntansi XIII Purwokerto, 1-28.

Indriani, Rini dan Wahiddatul Khoiriyah, 2010, Pengaruh Kualitas Pelaporan Keuangan Terhadap Informasi Asimetri, Simposium Nasional Akuntansi XIII Purwokerto

Indriantoro, N., dan B. Supomo, 2002, Metodologi Penelitian Bisnis untuk Akuntansi dan Manajemen. Edisi pertama. Yogyakarta: BPFE.

Munawir, 2004, Analisa Laporan Keuangan. Yogyakarta : Liberty.

Penman, S.H. and X.J. Zhang, 2002, Accounting Conservatism, the Quality of Earning and Stock Returns. Working Paper, Sosial Science Research Network, 1-44.

Setiany, Erna dan Wulandari, Ayu, 2015, Kualitas Pelaporan Keuangan dan Asimetri Informasi di Industri Manufaktur Indonesia. Efektif Jurnal Bisnis dan Ekonomi. Vol 6 No. 2, 17-24. 